\title{
Managing Cost of Quality in Laboratory of Water Analysis
}

\author{
Mouna Zahar ${ }^{1}$, Abdellah El barkany ${ }^{1} \&$ Ahmed El biyaali ${ }^{1}$ \\ ${ }^{1}$ Mechanical Engineering Laboratory, Faculty of Sciences and Technology, Sidi Mohamed Ben Abdellah \\ University, Fez, Morocco \\ Correspondence: Mouna Zahar, Mechanical Engineering Laboratory, Faculty of Sciences and Technology, Sidi \\ Mohamed Ben Abdellah University, Fez, Morocco. Tel: 212-619-696-955. E-mail: mouna_svt@hotmail.com
}

Received: October 31, 2014

Accepted: November 11, $2014 \quad$ Online Published: January 10, 2015

doi:10.5539/mas.v9n2p199

URL: http://dx.doi.org/10.5539/mas.v9n2p199

\begin{abstract}
Drinking water quality is of fundamental importance to human physiology and the durability of humanity. In today's environment, many laboratories of water analysis are challenged to maintain or increase their quality while simultaneously lowering their overall costs. The aim of this research is to classify and determine different quality costs in Moroccan laboratory of water analysis by implemented the Prevention-Appraisal-Failure (PAF) approach. Using data collected during six month, we found that approximately $77.9 \%$ of total quality costs was spent on costs of "good quality" (prevention and appraisal), while $22.1 \%$ was spent on costs of "poor quality" (internal and external failures). This is an ideal situation, prevention costs will be the largest portion of the total Cost of Quality (COQ). By minimizing delay and Claims (retest) can reduced external failure cost laboratory given weighted to customer needs because of the good quality of service. The cost of processing and correcting such errors was minimum. The fundamental point is to monitor the effects of the quality measures taken to reduce the number of failures. The article also explains the benefits of the eventual adoption of a COQ approach in laboratory, proper frame work and we propose guideline for significant and non-significant factors which should consider in laboratory of water analysis.
\end{abstract}

Keywords: cost of quality, appraisal costs, prevention costs, failure costs, water

\section{Introduction}

In the new and competitive world, it is important to have a reasonable cost and enough quality for firms. Nevertheless, making a balance between these parameters is more important. Not only must a firm provide its product to meet the client's requirements and at a quality that satisfies them, but it also must provide clients with the lowest cost possible. One effective way to achieve this purpose is using quality costs. Although there are numerous tools for measuring quality, the quality costs is considered by both Crosby (1984) and Juran (1988) to be the primary one. If firms and organizations can record and analyze the quality costs in their projects, they can use these data as a tool for identifying the roots of problems and having continuous improvements to reduce these costs in their projects. On the other hand, measurement of cost of quality is one of the most effective tools for evaluating the success of a quality management program.

There is a big problem in using this tool for firms and organizations. The first step to use quality costs is identifying and measuring them .Most quality costs are hidden and measuring them is difficult. On the other hand, contractors generally are not willing to exhibit their own costs and their quality problems such as reworks and omissions. So measuring and reporting the COQ should be considered an important effort for firms. Unfortunately in Morocco, it's not a proven matter that using the COQ system is cost-effective, and very few companies and firms measure their project's COQ.

This research project is relevant to the academic and industry fields. It fills a void in the current literature about COQ and expands the knowledge to a new sector of the economy. It also provides an illustration for applying COQ in laboratory of water analysis with future implications in other laboratory.

In this paper, we begin with a background of the COQ concept and their different models, followed by an illustration of how the PAF model of COQ can be applied in laboratory of water analysis. Finally, we discuss some of the advantages of this methodology. 


\section{Background on $\mathrm{COQ}$}

Juran (1951) and Feignebaum were the first scholars who urged the necessity of measurement of "Cost of Quality" (COQ) in quality related studies (Banasik, 2009). Feigenbaum (1956) pointed out the excessiveness of quality cost for many companies and inevitability to measure it for the sake of business's market position improvement. Based on the literature in 1950s, there were several factors which lead the quality authorities to measure quality costs. First of all, changes in the customer demands and request for more precise and reliable product have augmented the need of cost of quality measurement. On the other hand, the emergence of long life products, which imposed vast amount of repair, labor, maintenance and inventory costs on the manufacturer, made the provision of quality product more expensive than before. Furthermore, quality authorities needed a monetary language to express and motivate senior managers to participate in quality programs (Juran \& Gryna, 1993).

Even though the formation of COQ committee in American Society of Quality (ASQ) in 1967 was the first step to the systematic and global definition and classification of COQ, the definition of COQ has still not been agreed upon globally by the researchers and quality involved organizations. It means that there is not a single definition which has been accepted widely (Machowski \& Dale 1998).

Bank and Solórzano (1978) have defined the COQ as a cost incurred to keep the whole system at the predefined quality level. Clark and McLaughlin (1986) have divided COQ into two types of cost. First category refers to those costs which are related to the specifications in design and development phase and occur before delivery of product or service. The second category involves the costs which happen after the product delivery and are caused by the lack of conformance to the specified criteria.

The definition of Dale and Plunkett (1995) is the definition of COQ which is generally accepted by scholars. Schiffauerova \& Thomson (2006) have classified COQ into four categories. First includes the cost of planning, implementation and controlling any quality system in the organization, while the second category comprises the cost of resources which cross-functionally are committed to maintain or reach to specified quality level. The third category refers to the cost of quality failure and finally the fourth one to the other quality related costs.

In general COQ is assumed as a sum of amount of cost which an organization is paying in order to achieve a good quality and amount of cost which has been incurred due to the bad quality. The first COQ component is known as quality conformance cost and the latter as quality nonconformance cost. (Schiffauerova $\&$ Thomson, 2006).

British Standard Institution publication BS6143, (1981) developed its own definition of COQ. In 1990 they revised their definition and published "Guide to the Economics of Quality". The definition is comprised of two subdivisions. First is based on the process cost model and second is based on PAF model which will be defined later in this literature review. It defines COQ as "cost in assuring quality as well as loss incurred when quality is not achieved".

Loss of consensus over cost items in COQ is the fundamental reason why ambiguity exists in definition of COQ (Castillo-Villar, Smith et al. 2012). Dale and Plunkett (1991) stated that there is not an agreement between accountants in what to include as a COQ. Moreover it depends on the industry and also on the chief executive officer eagerness towards implementation of quality programs, because quality experts are adding more cost components or even dropping some cost components so as to signify their financial impact (Dale \& Plunkett , 1999) (Dadi, 2010).

Implication in definition of quality also made the definition of COQ more complicated. Castillo- Villar, smith et al. (2012) indicated that new trends in definition of quality like Juran definition "fitness to use" or Garvin's new dimension of quality, not only complicated definition of COQ but even added more intangible cost component to the COQ.

\section{Cost of Quality Models}

Since Juran (1951) discussed the cost of quality, many researchers have proposed various approaches to measuring COQ. Reviews of COQ literature can be found in (Vaxevanidis \& Petropoulos, 2008). In this section, we will briefly review the approaches to measuring COQ. In agreement with the majority of previous researchers present work classifies COQ models into five discrete generic groups which are: PAF or Crosby's model, opportunity cost models, process cost models and $\mathrm{ABC}$ models. These models are summarized in Table 1 . Obviously, models within one group are not identical; see comments in (Schiffauerova \& Thomson, 2006). 
Table 1. Generic COQ models and cost categories

\begin{tabular}{ll}
\hline Generic model & Cost /activity categories \\
\hline PAF models & Prevention+ appraisal+ failure \\
Crosby's model & Prevention+ appraisal+ failure+ opportunity \\
& Conformance + non-conformance \\
Opportunity or intangible cost models & Conformance + non-conformance + opportunity \\
& Tangible + intangibles \\
Process cost models & PAF (failure cost includes opportunity cost) \\
ABC models & Conformance + non-conformance \\
\hline
\end{tabular}

\section{The Traditional PAF Model:}

The traditional PAF model involves the costs coming from three sources of activities: Prevention, appraisal and failure. (Figure 1) (Zimwara, Mugwagwa et al. 2013)

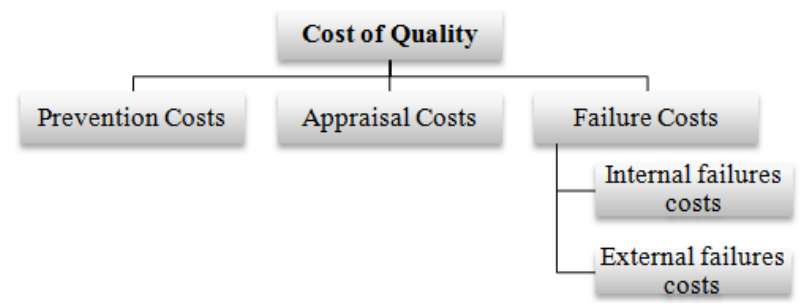

Figure 1. Cost of quality categories

Prevention costs are known as the costs incurred for preventing non-conformities by ensuring the process in place is capable of delivering high quality products or services. Love \& Irani (2003) best described prevention costs as all amounts spent or invested to prevent or reduce errors or defects, that is, to finance activities aimed at eliminating the causes of defects.

Appraisal costs are in association with the measurement system used to appraise the quality of a product or service. In other words it is the detection of errors or defects by measuring conformity to the required level of quality: incoming and completed material inspection (Love \& Irani, 2003).

Failure costs are the efforts in place to correct a non-conformity that has taken place before or after delivery to the customer. Failure costs are thereby classified as Internal Failures (IF) and External Failures (EF). Internal failures would include costs due to scrapping or reworking defective product or compensation for delays in delivery whereas external failures would include costs that are incurred once the product or service has been delivered to customer such as cost of repairs, returns, dealing with complaints and compensations. (Arabian, Jourabchi et al. 2013) (Figure 2).

Quality cost calculation in this case is performed according to formula:

$$
\mathrm{COQ}=\mathrm{P}+\mathrm{A}+\mathrm{IF}+\mathrm{EF}
$$

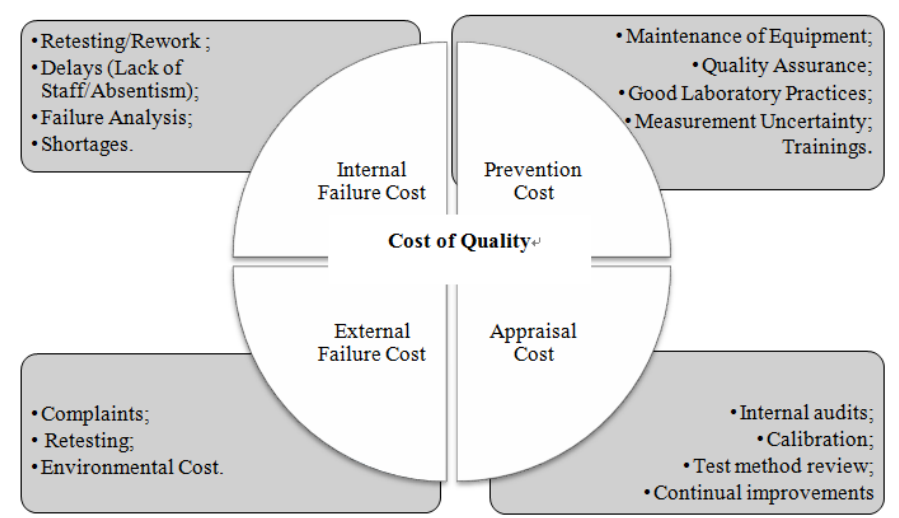

Figure 2. Examples of quality costs Associated with water analysis Laboratory 


\section{Methodology}

The COQ model used is the most commonly, which is PAF model. During six month (April-September), we calculated and discussed quality costs in Moroccan laboratory of water analysis located in fez. Useful parameters of sanitary effects of drinking water human (NM.03.7001, 1991) are presented in table 2, followed by an analysis bulletin example of potable water in south of fez is presented in table 3. (Moroccan standards catalog, 2014).

Table 2. Parameters of sanitary effects of potable water

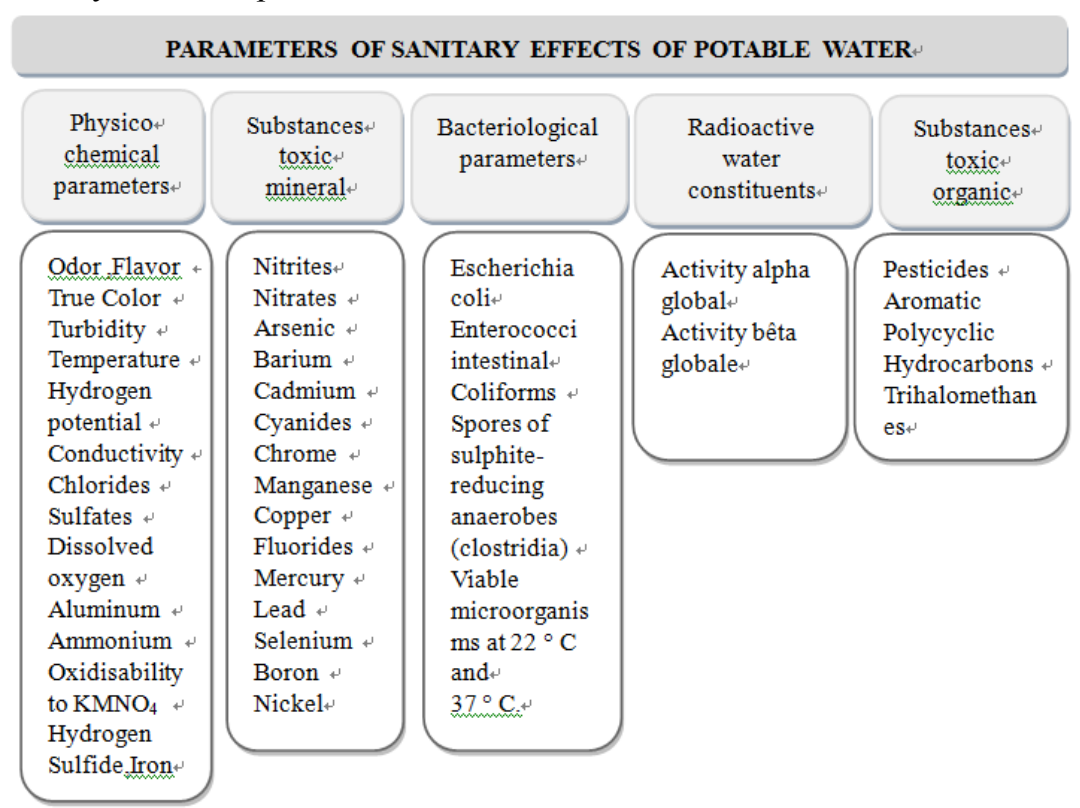

Table 3. Analysis bulletin example of potable water in south of Fez

\begin{tabular}{|c|c|c|c|c|}
\hline Parameters & Method & Unit & $\begin{array}{l}\text { Maximum } \\
\text { allowable } \\
\text { value } \\
\end{array}$ & $\begin{array}{ll}\text { Sample of } \\
\text { drinking } \\
\text { water }\end{array}$ \\
\hline \multicolumn{5}{|l|}{ Residual disinfection treatment } \\
\hline Free residual chlorine & NM 03.7.007 & $\mathrm{mg} / \mathrm{L}$ & $<=1$ & 0.45 \\
\hline \multicolumn{5}{|l|}{ Organoleptic parameters } \\
\hline Flavor & NM 03.7.017 & & $<=3$ & - \\
\hline Odor & NM 03.7.016 & & $<=3$ & - \\
\hline True Color & NM 03.7.018 & Pt mg/l & $<=20$ & - \\
\hline \multicolumn{5}{|l|}{ Bacteriological parameters } \\
\hline Intestinal enterococci at $36^{\circ} \mathrm{C} / 48 \mathrm{H}$ & NM 03.7.006 & $\mathrm{UFC} / 100 \mathrm{ml}$ & $=0$ & 0 \\
\hline Coliforms at $37^{\circ} \mathrm{C} / 24$ & NM 03.7.003 & $\mathrm{UFC} / 100 \mathrm{ml}$ & $=0$ & 0 \\
\hline Escherichia coli at $44^{\circ} \mathrm{C} / 48 \mathrm{H}$ & NM 03.7.003 & $\mathrm{UFC} / 100 \mathrm{ml}$ & $=0$ & 0 \\
\hline Viable microorganisms at $22^{\circ} \mathrm{C} / 68 \mathrm{H}$ & NM 03.7.005 & $\mathrm{UFC} / \mathrm{ml}$ & $<=100$ & 0 \\
\hline Viable microorganisms at $37^{\circ} \mathrm{C} / 48 \mathrm{H}$ & NM 03.7.005 & $\mathrm{UFC} / \mathrm{ml}$ & $<=20$ & 0 \\
\hline $\begin{array}{l}\text { Spores anaerobic microorganisms at } \\
37^{\circ} \mathrm{C} / 24 \mathrm{H}\end{array}$ & NM 03.7.004 & $\mathrm{UFC} / 100 \mathrm{ml}$ & $=0$ & - \\
\hline \multicolumn{5}{|l|}{ Physico-chemical parameters } \\
\hline Temperature & NM 03.7.008 & ${ }^{\circ} \mathrm{C}$ & Acceptable & 25 \\
\hline $\mathrm{pH}$ & NM 03.7.009 & - & $6.5-8.5$ & 7.75 \\
\hline Conductivity & NM 03.7.011 & $\mu \mathrm{S} / \mathrm{cm}$ & $<=2700$ & 646 \\
\hline Turbidity & NM 03.7.010 & NTU & $<=5$ & 0.15 \\
\hline
\end{tabular}

The total COQ expenses for our laboratory during the six month study period were $10,848 \$(30 \%$ of the total direct laboratory expenses), approximately $77.9 \%$ of total COQ was spent on costs of good quality (48.4\% 
prevention costs and $29.5 \%$ appraisal costs), and $22.1 \%$ of COQ was spent on costs of poor quality (11.6\% internal failure costs and $10.5 \%$ external failure costs) (table 4 ).

Table 4. Cost of quality expenses by category

\begin{tabular}{llll}
\hline & & Total COQ & \% of total COQ \\
\hline $\begin{array}{l}\text { Internal Failure Costs } \\
\text { Reworking }\end{array}$ & $690 \$$ & $1,260 \$$ & $11.6 \%$ \\
$\begin{array}{l}\text { Delays } \\
\text { External Failure Costs }\end{array}$ & $570 \$$ & & \\
Complaints (for retesting) & $600 \$$ & $1,142 \$$ & $10.5 \%$ \\
$\begin{array}{l}\text { Environmental cost } \\
\text { Appraisal Costs }\end{array}$ & $542 \$$ & & \\
Calibration & & \\
Purchase of chemicals and reagents & $2,300 \$$ & $3,200 \$$ & $29.5 \%$ \\
Prevention Costs & & & \\
Machines maintenance & $2,650 \$$ & & \\
Training (for 3 technician) & $1,385 \$$ & $5,246 \$$ & $48.4 \%$ \\
Errors proofing & $1,211 \$$ & & \\
\hline
\end{tabular}

In this study prevention costs is the largest portion of the Total Cost of Quality. Appraisal costs should be the second largest category, but should not exceed prevention costs and internal failure cost. (Figure 3). All costs resulting from services not conforming to requirements or customer which occur before delivery of product, or the furnishing of a service. Examples include rework, retesting. The goal is to identify all internal failures and resultant costs, and then systematically identify and eliminate root causes until internal failure costs are eliminated external failure cost. By minimizing delay and Claims (retest) can reduced external failure cost. The training programs or awareness programs which are important can be strengthened to have a control on the preventive costs. More emphasis can be given to the preventive measures and activities.

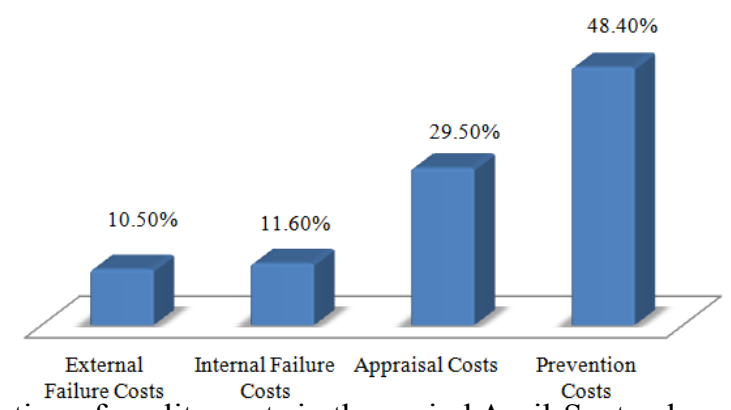

Figure 3. Distribution of quality costs in the period April-September of the studies

\section{Discussion}

Now days, increasing in competitive environment at both national and international level forced the businesses to produce customer-based and also this environment has forced the businesses to provide quality to satisfy the customer needs. The model use in this study is the classical prevention-appraisal-failure (PAF). The study indicates that the quality of laboratory test results can be regarded as good based but improvements are required to minimize delay.

Laboratory taken systematic quality initiatives; however, a formal COQ methodology was only employed. As each cost factors affects the other, a systematic approach is needed to recognize both the effects of factors on each other and quality level of products /services.

The article explains the benefits of the eventual adoption of a COQ approach in water laboratory, proper frame work and we propose guideline for significant and non-significant factors which should consider in laboratory of water analysis. Laboratory knows exactly what its conformance and non-conformance costs are. At the same time, they adopt systematic quality improvement programs in order to reach a zero defect quality level.

Conformance costs are consequently given much less attention in the quality management programs and 
measuring them together with the cost of non-conformance. It has been suggested that the cost of poor quality can range from $15 \%-40 \%$ of business costs (Mohandas \& Sankar, 2008).

\section{Conclusion}

In recent years organizations have been focusing much attention on quality management. To maximize the profits of an organization it is necessary to monitor quality costs. Laboratory of water analysis has a strong quality strategy in order to survive in the competitive world. Focusing on prevention and appraisal cost this laboratory reduced all type failures which lead to increase profit and good reputation in market. Laboratory focus on cost of conformance and decrease cost of non conformance.

Cost of quality has a powerful based on the effect of quality costs on the level of customer satisfaction; it has been proved that increasing prevention costs and decreasing external failure costs can directly improve the level of customer satisfaction. Cost of quality has also direct effect on service cost and indirect effect on Profitability (Aigbavboa \& Thwala, 2014). In order to improve quality an organization must take into account the costs associated with achieving quality since the objective of continuous improvement programs is not only to meet customer requirements, but also to do it at the lowest cost (Castillo-Villar, Smith et al. 2014). COQ focuses on process improvement and the elimination of all forms of waste.

Laboratory measure, monitor and work mostly with the cost of non-conformance. This program mainly facilitates identification of the target areas for quality improvement and cost reduction in quality effort the methodology is not complex. COQ decrease defects, overall costs, customer complaints and increase sales, profit, capacity, customer satisfaction, employee satisfaction This COQ programs provide a good method for identification and measurement of quality costs, and thus allow targeted action for reducing COQ.

Further education on the practical level is needed for managers to understand better the COQ concept in order to appreciate fully the benefits of the approach, to increase their ability to implement a COQ measurement system and to save money.

\section{Acknowledgments}

The authors are indebted to the many colleagues at the laboratory of water analysis who have contributed significantly to the development of this approach. This approach only works if there is effective collaboration between all those who share knowledge and experience of the assets.

\section{References}

Aigbavboa, C., \& Thwala, W. (2014) .An assessment of critical success factors for the reduction of the cost of poor quality from construction projects in South Africa. Proceedings 30th Annual ARCOM Conference, 773-782.

Arabian, T., Mehdi, J. S. M., Leman, Z., \& Ismail, M. Y. (2013). A Research on the Impact of Cost of Quality Models and Reporting System on Managing Cost of Quality. International Proceedings of Economics Development and Research, 59(11). http://dx.doi.org/10.7763

Banasik, M. (2009). A study of the costs of quality in a renewable resource environment. $\mathrm{PhD}$ in systems and Engineering Management, Texas Tech University, Lubbock.

Blank, L., \& Solorzano, J. (1978). Using quality cost analysis for management improvement. Industrial Engineering, 10(2), 46-51.

Castillo-villar, K. K., Smith, N. R., \& José, F. H. (2014). Design and Optimization of Capacitated Supply Chain Networks Including Quality Measures. Mathematical Problems in Engineering, 17. http://dx.doi.org/10.1155/2014/218913

Castillo-villar, K. K., Smith, N. R., \& Simontoncy, J. L. (2012). A model for supply chain design considering the

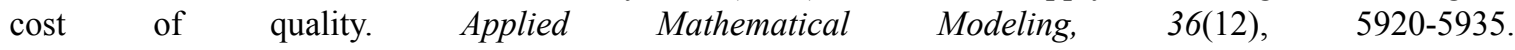
http://dx.doi.org/10.1016/j.apm.2012.01.046

Castillo-villar, K. K., Smith, N. R., \& Simontoncy, J. L. (2012). The impact of the cost of quality on serial supply-chain network design. International Journal of Production Research, 50(19), 5544-5566. http://dx.doi.org/10.1080/00207543.2011.649802

Clark, H. J., \& Tannock, J. D. T. (1999). The development and implementation of a simulation tool for the assessment of quality economics within a cell-based manufacturing company. International Journal of Production Research, 37(5), 979-995. http://dx.doi.org/10.1080/002075499191364

Crosby, P. B. (1984). Quality without tears: The art of hassle-free management. New York, NY: McGraw-Hill. 
Dadi, H. (2010). Engineering Quality Systems: Cost of Quality. Modern Applied Science, 4(5), 102-104.

Dale, B. G., \& Plunkett, J. J. (1999). Quality costing. Gower Publishing, Ltd.

Feigenbaum, A. V. (1956). Total quality Control. Harvard business review, 34(6), 93-101.

Juran, J. M., \& Gryna, F. M. (1988). Juran’s Quality Control Handbook. New York, NY: McGraw-Hill.

Juran, J. M., \& Gryna, F. M. (1993). Quality planning and analysis: from product development through use. New York: McGraw-Hill.

Juran, J. M. (1951). Quality Control Handbook. New York, NY: McGraw-Hill.

Love, P., \& Zahir, I. (2003). A Project Management Quality Cost Information System for the Construction Industry. Information \& Management, 40. http://dx.doi.org/10.1016/S0378-7206(02)00094-0

Machowski, F., \& Dale, B. G. (1998). Quality costing: An examination of knowledge, attitudes, and perceptions. Quality Management Journal, 5(3).

Mohandas, V. P., \& Sankara, R. S. (2008). Cost of Quality Analysis: Driving Bottom-line Performance. International Journal of Strategic Cost Management, 3(2).

Plunkett, J. J., \& Dale, B. G. (1988). Quality costs: A critique of some economic cost of quality models. International Journal of Production Research, 1713-1726. http://dx.doi.org/10.1080/00207548808947986

Schiffauerova, A., \& Thomson, V. (2006). A review of research on cost of quality models and best practices. International Journal of Quality and Reliability Management, 23(6), 647-669. http://dx.doi.org/10.1108/02656710610672470

Vaxevanidis, N. M., \& Petropoulos, G. (2008). A literature survey of cost of quality models. Annals of the faculty of engineering hunedoara - Journal of engineering. Tome VI. Fascicule 3.

Zimwara, D., Mugwagwa, L., Maringa, D., Mnkandla, A., Mugwagwa, L., \& Ngwarati, T. (2013). Cost of Quality as a Driver for Continuous Improvement - Case Study? Company X. International Journal of Innovative Technology and Exploring Engineering, 2(2).

\section{Copyrights}

Copyright for this article is retained by the author(s), with first publication rights granted to the journal.

This is an open-access article distributed under the terms and conditions of the Creative Commons Attribution license (http://creativecommons.org/licenses/by/3.0/). 